\title{
Konstruksi Epistimologi Kurikulum Pendidikan Bahasa Arab Perspektif Mahmud Kamil An-Naqoh
}

\author{
Syindi Oktaviani R. Tolinggi \\ UIN Sunan Kalijaga Yogyakarta, Indonesia \\ Email: syindioktaviani0410@gmail.com
}

\begin{abstract}
In the preparation of the curriculum, it must pay attention to the epistemological foundation by looking at some of the ideas of Arabic language education experts about it, among them are the ideas of Mahmud Kamil An Naqoh. This article aims to examine the epistemology of the Arabic language curriculum from the perspective of Mahmud Kamil An Naqoh. This type of research is literature review. The results of this study found that there are four bases that form the basis of developing the Arabic curriculum of Mahmud Kamil An Naqoh's perspective, namely: (1) linguistic/allughawiyyah basis, (2) socio-cultural/aś-sंaqāfiyyah basis, (3) basic psychology/annafsiyyah, and (4) educational / at-tarbawiyyah basis. However, of the four divisions, Mahmud Kamil An Naqoh still divides them into five parts, namely: (1) experience and practice of language/al-khibroh al-lughawiyah wa al-mumārosah, (2) the nature of Arabic/tobī'atu al-lughah al-'Arabiyah, (3) Arab social culture/aś-śaqōfah al- 'Arabiyah, (4) the nature of language learners/tobìatu al-muta'allimin lilughah, and (5) the nature of teaching Arabic as a foreign language/ tobì'atu 'amaliyatu ta'lim al-' Arabiyah bi itibārohā lughah ajnabiyah. So from the basis of the epistemology the five curriculum components according to Mahmud Kamil An Naqoh, namely: (1) objectives/al-ahdaf, (2) contents or material/al-muhtawa, (3) methods / at-țuruqu, (4) guidelines Arabic teacher/dalīlu mu'allim al-lughah al-'Arabiyah, and (5) evaluation/(at-taqwìm.

Keyword:Epistemology, Curriculum, Arabic
\end{abstract}

\begin{abstract}
Abstrak: Penyusunan kurikulum haruslah memperhatikan landasan epistimologi dengan melihat beberapa gagasan pakar pendidikan bahasa Arab mengenai hal tersebut, di antaranya adalah gagasan Mahmud Kamil An-Naqoh. Artikel ini bertujuan untuk mengkaji tentang epistimologi kurikulum bahasa Arab perspektif Mahmud Kamil An-Naqoh. Jenis penelitian ini adalah kajian pustaka. Hasil penelitian ini menemukan ada empat dasar yang menjadi landasan menyusunan kurikulum bahasa Arab perspektif Mahmud Kamil An-Naqoh, yaitu: (1) dasar linguistik/al-lughawiyyah, (2) dasar sosial-budaya/aś-śaqāfiyyah, (3) dasar psikologi/an-nafsiyyah, dan (4) dasar edukatif/at-tarbawiyyah. Akan tetapi dari ke empat pembagian tersebut, Mahmud Kamil An-Naqoh masih membaginya lagi menjadi lima bagian, yaitu: (1) pengalaman dan praktik bahasa/al-khibroh al-lughawiyah wa al-mumārosah, (2) sifat bahasa Arab/tobīatu al-lughah al-'Arabiyah, (3) sosial budaya Arab/aś-śaqōfah al- 'Arabiyah, (4) sifat pembelajar bahasa (peserta didik)/țobīatu al-muta`allimin lilughah, dan (5) sifat pengajaran bahasa Arab sebagai bahasa Asing/țobīatu 'amaliyatu ta'lim al'Arabiyah bi ìtibārohā lughah ajnabiyah.Sehingga dari dasar epistimologi tersebut terumuslah lima komponen kurikulum menurut Mahmud Kamil An-Naqoh, yaitu: (1) tujuan/al-ahdāf, (2) isi/materi/al-muhtawā, (3) metode/aț-țruqu, (4) panduan pengajar/guru bahasa Arab/dalīlu mu`allim al-lughah al-`Arabiyah, dan (5) evaluasi/at-taqwìm.
\end{abstract}

Kata Kunci: Epistimologi, Kurikulum, Bahasa Arab

\section{PENDAHULUAN}

Pada awalnya, tujuan mempelajari bahasa Arab di Indonesia hanya sebatas untuk kepentingan ibadah saja seperti shalat, doa, dzikir, dan kepentingan 
untuk mendekatkan diri kepada Allah swt. Kemudian tujuan mempelajari bahasa Arab berkembang, seiring dengan bahasa Arab menjadi sarana untuk memahami sumber-sumber syariat agama, seperti al-Qur`an, hadist, dan buku-buku berbahasa Arab lainnya.Akan tetapi metode pembelajaran yang digunakan pada saat itu, masih sangat klasik yaitu metode qawā'id dan tarjamah yang digunakan dalam pembelajaran kitab-kitab agama Islam.

Kemudian seiring dengan perkembangan zaman, pemahaman orang Indonesia mengenai bahasa Arab semakin terbuka lebar. Mereka mengetahui bahwa bahasa Arab tidak cukup hanya digunakan untuk keperluan ibadah dan membaca kitab-kitab klasik (Arab) saja. Sehingga di Indonesia muncul pondok pesantren Gontor dengan pemahaman yang baru dalam hal pembelajaran bahasa Arab, yaitu tidak hanya mementingkan penggunaan metode qawā'id dan tarjamah, tetapi juga menggunakan al-istimā' dan al-kalām karena menganggap bahasa Arab juga merupakan sarana penyampaian informasi antar manusia. Setelah itu, pembaharuan pada pembelajaran bahasa Arab di Indonesia dikuti oleh sekolahsekolah dan universitas yang melakukan pengembangan pembelajaran bahasa Arab beserta kurikulumnya. ${ }^{1}$.

Kurikulum merupakan salah satu alat yang digunakan untuk mencapai tujuan pendidikan sekaligus merupakan pedoman dalam pelaksanaan pembelajaran pada semua jenis dan jenjang pendidikan. Tanpa kurikulum yang sesuai dan tepat, akan sulit untuk mencapai tujuan dan sasaran pendidikan yang diinginkan. ${ }^{2}$

Kurikulum (manhaj) merupakan "jantung" institusi pendidikan atau sistem pembelajaran.Tanpa kurikulum, proses pembelajaran termasuk pembelajaran bahasa Arab menjadi tidak jelas arah dan orientasinya. ${ }^{3}$ Al-Jabburi dan As-Sulthani (2013) mengatakan bahwa kurikulum mempunyai posisi yang strategis dan merupakan kunci dalam proses pendidikan karena kurikulum

${ }^{1}$ Enjang Burhanudin Yusuf, "Implementasi Kurikulum Bahasa Arab di Perguruan Tinggi Agama Islam (PTAI) di Indonesia, Tarling: Jurnal of Language Education, Vol. 1, No. 1, 2018, 1.

${ }^{2}$ Ahmad Nurcholis dan Basmah Salaeh, "Epistimologi Kurikulum Bahasa Arab di Sekolah Menengah Mutawasitah Piraya Nawin Klonghin Wittaya Patani Thailand Selatan, Arabi: Journal of Arabic Studies, Vol. 4, No. 1, 2019, 2.

${ }^{3}$ Nur Chotimah, "Urgensi Filsafat Bahasa dalam Pengembangan Kurikulum Pembelajaran Bahasa Arab, Turats: Jurnal Kajian Ilmu Pendidikan Bahasa Arab dan Peradaban, Vol. 7, No. 1, 2015, $2-3$. 
merupakan bagian pendidikan yang akan menentukan arah, isi dan proses pendidikan, yang pada akhirnya akan menentukan arah dan kualifikasi lulusan suatu lembaga pendidikan. ${ }^{4}$

Muhbib Abdul Wahab, menambahkan bahwa kurikulum (curriculum, almanhaj) yang secara bahasa berarti jalan yang jelas tidak hanya berupa struktur mata pelajaran dan silabus melainkan keseluruhan pengetahuan, keterampilan, pengalaman, dan kepribadian yang akan ditransformasikan melalaui proses pendidikan, sehingga peserta didik akan mengalami perkembangan dan kemajuan ke arah terbentuknya pribadi yang berpikir rasional, berpengatahuan laus, bersikap positif, berketerampilan dan berkepribadian sosial. ${ }^{5}$

Maka berdasarkan pendapat di atas, dapat dilihat bahwa kurikulum merupakan elemen yang sangat penting dalam sistem pendidikan karena kurikulum ibarat peta, alat, dan petunjuk umum yang digunakan untuk mencapai tujuan-tujuan di dalam pendidikan tersebut. Keberbasilan suatu pendidikan ditentukan oleh kurikulum yang baik dan sesuai dengan kebutuhan peserta didik. Jika struktur dan bangunan sebuah kurikulum yang digunakan bersifat komperhensif dan menyeluruh, maka output yang dihasilkan dari proses pendidikan yang dilakukan akan menjadi baik pula, demikian juga sebaliknya.

Melihat betapa pentingnya peran kurikulum di dalam pelaksanaan sebuah pembelajaran,menurut Enjang, kurikulum harus disusun secara strategis dan harus mempertimbangkan berbagai macam aspek seperti perkembangan anak, perkembangan ilmu pengetahuan, perkembangan kebutuhan masyarakat, lapangan kerja dan sebagainya, serta mesti dibuatkan model-model pengembangan kurikulum yang disesuaikan dengan kondisi lingkungan dan kebutuhannya. 6

Oleh karena itu dalam penyusunan kurikulum bahasa Arab hendaknya melihat dari berbagai aspek, melihat kebutuhan siswa, masyarakat dan pelaku pendidikan.Dalam perumusan kurikulum harus mempertimbangkan berbagai

${ }^{4}$ Muhbib Abdul Wahab, "Standarisasi Kurikulum Pendidikan Bahasa Arab di Perguruan Tinggi Keagamaan Islam Negeri, Arabiyat: Jurnal Pendidikan Islam dan Kebahasaaraban, Vol. 3, No. 1, 2016, 37.

${ }^{5}$ Ibid.

${ }^{6}$ Enjang Burhanudin Yusuf, "Implementasi Kurikulum Bahasa Arab di Perguruan Tinggi Agama Islam (PTAI) di Indonesia, 47. 
faktor dan variabel yang terkait dengan beberapa hal, misalnya hakikat dan fungsi bahasa, aspek sosialinguistik, psikologi peserta didik, beserta sistem pendidikan dan pembelajaran. Agar tidak mengalami disorientasi dalam tujuan pembelajaran bahasa Arab, maka kurikulum pendidikan bahasa Arab perlu dibangun atau dikonstruksi berdasarkan epistemologinya yang sesuai.

Setiap kurikulum pendidikan yang diterapkan dalam setiap institusi dan lembaga pendidikan, menurut Humaidi dalam penelitiannya niscaya harus memiliki fondasai epistemologi.7 Fondasi epistemologi ini dalam membangun kurikulum misalnya diawali dari pertanyaan, ilmu apa yang akan dijelaskan dan diberikan kepada peserta didik? Atau ilmu apa yang akan disampaikan terlebih dahulu? Mengapa ilmu fonologi misalnya, harus diajarkan terlebih dahulu dibandingkan dengan ilmu sharf dan nahwu atau ilmu semantik? Untuk apa ilmuilmu tersebut diajarkan? Secara epistemologis, pertanyaan-pertanyaan tersebut menjadi landasan awal dalam menyusun kurikulum.

Adapun dalam penyusunaan fondasi epistimologi kurikulum, diperlukan melihat gagasan beberapa pakar dalam bidang bahasa Arab dan pembelajaran bahasa Arab, diantaranya adalah Mahmud Kamil An-Naqoh yang merupakan salah seorang pakar dalam bidang pendidikan, metode pembelajaran dan struktur pembelajaran bahasa Arab. Oleh karena itu, tujuan dari penelitian ini adalah memberikan gambaran tentang bagaimana konstruksi epistimologi kurikulum bahasa Arab jika ditinjau dari perspektif Mahmud Kamil An-Naqoh sebagai seorang pakar yang bergerak di bidang pembelajaran bahasa Arab.

Berdasarkan literatur review yang berkaitan dengan tema penelitian ini, penulis menemukan ada beberapa penelitian yang berkaitan dengan kajian mengenai gagasan Mahmud Kamil An-Naqoh, yaitu:

Pertama, Tesis yang berjudul Fikrotu Mahmud Kamil An-Naqoh fi Ta`īm Mahārōt Al Lughat Al 'Arobiyyat Lighairi An Nāțiqīna Bihā oleh Akmal Firdaus Sultra tahun 2016.8 Tesis ini secara khusus membahas tentang gagasan Mahmud Kamil An-Naqoh dalam pembelajaran keterampilan berbahasa Arab bagi penutur asing (non Arab). Bagaimana tujuan dari pembelajaran empat keterampilan yaitu

${ }^{7}$ Humaidi, “Epistimologi Kurikulum Pendidikan Sains, Jurnal Pendidikan Sains, Vol. 2, No. 2 (2013), 264.

${ }^{8}$ Akmal Firdaus Sultra, "Fikrotu Mahmud Kāmil An Nāqoh fi Ta līm Mahārōt Al Lughat Al ‘Arobiyyat Lighairi An Nāṭiqina” (Tesis, UIN Maulana Malik Ibrahim Malang, 2016). 
berbicara (mahāratu al-kalām), mendengar (mahāratu al-istimā'), membaca (mahāratu al-qirā’ah) dan menulis (mahāratu al-kitābah) dilengkapi dengan komponen, aspek, strategi dan metode pembelajaran masing-masing keterampilan tersebut.

Kedua, Artikel Jurnal yang berjudul Pembelajaran Mahārat Al Kalām Menurut Rusdy Ahmad Thu'aimah dan Mahmud Kamil An-Naqoh oleh Yazid Hady tahun 2019. ${ }^{9}$ Pembahasan di dalam artikel tersebut lebih mengarah kepada desain kurikulum pembelajaran bahasa Arab berdasarkan teori pembelajaran mahārat al kalām menurut Rusdy Ahmad Thu'aimah dan Mahmud Kamil An-Naqoh. Di dalam penelitian tersebut dikatakan bahwa, urgensi kemahiran berbicara dalam konteks pembelajaran bahasa Asing terdapat pada aspek lisan dalam bahasa itu sendiri. Kemahiran berbicara merupakan aspek utama dalam kurikulum pembelajaran bahasa Asing. Pendapat ini jelas mengindikasikan bahwa kemahiran berbicara (kalām) mengisyaratkan keberhasilan seseorang dalam berbahasa dan mengetahui bahasa tersebut. Karena kemahiran ini sangat terkait dengan pelafalan, gramatika, kosakata, keterampilan mendengarkan, dan lain lain. Oleh karena itu, penggunaan metode dan strategi atau teknik yang didasari oleh pendekatan (approach) yang tepat akan berpengaruh terhadap hasil dari tujuan pembelajaran bahasa tersebut.

Dari hasil literatur review di atas, peneliti sebelumnya hanya membahas mengenai gagasan Mahmud Kamil An-Naqoh dari segi keterampilan berbahasa saja, sehingga menunjukkan bahwa belum ada penelitian yang mengkaji gagasan Mahmud Kamil An-Naqoh terkait dengan asas-asas atau konstruksi epistimologi kurikulum bahasa Arab perspektif Mahmud Kamil An-Naqoh, sebagaimana maksud dan tujuan artikel ini.

\section{METODE PENELITIAN}

Penelitian ini merupakan penelitian studi pustaka (Library Research), yaitu penelitian yang pengumpulan datanya dilakukan di perpustakaan dengan didasarkan atas pembacaan terhadap beberapa literatur yang dapat memberikan informasi serta memiliki relevansi dengan topik penelitian. Sumber data diambil dari eksplorasi literatur kepustakaan terkait topik penelitian, baik mengenai

${ }^{9}$ Yazid Hadi, "Pembelajaran Mahārat Al Kalām Menurut Rusdy Ahmad Thu’aimah dan Mahmud Kāmil An Nāqoh”, Al Mahāra: Jurnal Pendidikan Bahasa Arab, Vol. 5, No. 1, 2019, 63-84. 
kurikulum bahasa Arab secara menyeluruh maupun kurikulum bahasa Arab dan pembelajarannya yang didapatkan dari sumber buku-buku karangangan Mahmud Kamil An-Naqoh, kemudian dianalisa mendalam dengan cara reduksi data, penyajian data dan penarikan kesimpulan.

\section{HASILPENELITIAN}

\section{Hakikat Epistimologi}

Epistemologi berasal dari bahasa Yunani "episteme" (pengetahuan) dan "logos" (kata/pembicaraan, teori) adalah cabang filsafat yang berkaitan dengan asal, sifat, dan jenis pengetahuan. Epistemologi membahas bagaimana ilmu diperoleh, dibangun, dan dikonseptualisasikan.Topik ini termasuk salah satu yang paling sering diperdebatkan dan dibahas dalam bidang filsafat, misalnya tentang apa itu pengetahuan, bagaimana karakteristik, kategori, serta hubungannya dengan kebenaran dan keyakinan. ${ }^{10}$

Epistemologi disebut juga teori pengetuhuan (nazhariyyat al-ma'rifah), yaitu teori tentang asal-usul, sumber, cara pemerolehan, kerangka metodologis, dan bangunan ilmu pengetahuan. Jika ontologi mempertanyakan apa yang dikaji oleh sebuah ilmu; aksiologi mempermasalahkan untuk apa ilmu digunakan dalam kehidupan, maka epistemologi mengkritisi bagaimana ilmu itu diperoleh dan dikembangkan dalam suatu bingkai atau bangunan pengetahuan yang utuh, sistematis, integratif dan interkonektif. Tanpa epistemologi sebuah ilmu menjadi tidak jelas landasarn keilmuan, akar historis, objek formal dan material berikut substansi kajiannya, dan kerangka metodologisnya. ${ }^{11}$

Epistemologi mengkaji dan mengkritisi status suatu bidang keilmuan. Hal ini penting dilakukan karena tiga alasan yang saling berkait. Pertama, fungsi utama ilmu adalah menjelaskan (explaining). Sebuah ilmu dikatakan dapat berfungsi jika dapat menjelaskan dengan lugas dan sistematis status ilmu itu sendiri dan objek yang dipelajarinya.Ilmu bahasa Arab, misalnya, dapat dianggap sah sebagai ilmu jika bangunan ilmu ini dapat menjelaskan status keilmuannya di satu pihak, dan

${ }^{10}$ Muhbib Abdul Wahab, "Standarisasi Kurikulum Pendidikan Bahasa Arab di Perguruan Tinggi Keagamaan Islam Negeri, 35.

11 Ibid. 
objek kajian atau materi dan substansi yang menjadi wilayah studinya. ${ }^{12}$ Dengan kata lain, dengan epistemologi kita akan dibawa kepada pemahaman mengenai seperti apa seharusnya konsep logis, metodis dan sistematis dari ilmu tersebut. Mempertanyakan status keilmuan tidak hanya penting untuk mengetahui "profil ilmu", tetapi juga dapat menyikapi bagaimana seharusnya ilmu kebahasaaraban itu, termasuk kurikulum PBA, dikembangkan.

Kedua, sifat ilmu adalah dinamis, akumulatif, dan logis. Ilmu tidak lahir dan langsung besar, matang dan kaya (informasi dan teori). Ilmu berkembang secara bertahap dan berkelanjutan. Ilmu dibangun dengan logika keilmuan: berpikir rasional, sistematis dan metodologis. Sesuai dengan karakter ilmu yang cenderung progresif (berkembang dinamis dan akumulatif), ilmu bahasa Arab idealnya juga tidak stagnan, melainkan terus berkembang dan menjadi maju. Hal yang masih menjadi persoalan adalah sudah sampai mana dinamika dan progresivitas ilmu-ilmu bahasa Arab ini dikembangkan?13

Ketiga, arah pengembangan keilmuan bahasa Arab di masa depan perlu diletakkan pada landasan epistemologisnya secara kokoh dan benar. Kesulitan besar akan dialami dalam mengkaji dan mengembangkan suatu disiplin ilmu jika tidak diketahui dasar-dasar epistemologis ilmu itu. Demikian pula, pengembangan ilmu bahasa Arab akan mengalami disorientasi apabila sejarah perkembangan, landasan epistemologi, dan kerangka metodologi ilmu bahasa Arab tidak dipahami secara memadai. ${ }^{14}$

Sedemikian pentingnya epistemologi ilmu-ilmu bahasa Arab agar pengembangan kurikulum pendidikan dan pembelajaran bahasa Arab dapat dilakukan sesuai dengan kebutuhan, tuntutan keilmuan, dan perkembangan zaman. Adapun terkait dengan episotimologi kurikulum baahsa Arab, para pakar dalam bidang pendidikan bahasa Arab memiliki perspektif yang berbeda-beda terkait dengan hal tersebut, termasuk Mahmud Kamil An-Naqoh.

\section{Biografi Mahmud Kamil An-Naqoh}

Dr. Mahmud Kamil An-Naqoh merupakan nama populer dari Dr Mahmud Kamil Hasan An-Naqoh. Salah seorang pakar dalam bidang bahasa Arab, 
khususnya dalam bidang pendidikan, metode pembelajaran dan struktur pembelajaran bahasa Arab. Mahmud Kamil An-Naqoh mempunyai kepribadian yang baik dalam sesuatu yang berhubungan dengan diskusi, sepertihalnya ketika memberikan solusi dan masukan apabila ada prolematika dalam pembelajaran bahasa Arab. ${ }^{15}$

Mahmud Kamil An-Naqoh lahir pada tanggal 1 Agustus 1939 M di desa Abyaulhamra', di Ibukota Buhairoh. Beliau bayak mendapatkan ijazah keilmuan akademik dan mempunyai banyak jabatan yang berbeda, akan tetapi kebanyakan berhubungan dengan pedidikan dan metode pembelajaran. ${ }^{16}$

Keahlian dan ijazah keilmuan yang diperoleh Mahmud Kamil An-Naqoh adalah sebagai berikut: 1) Sekolah strata satu sastra dari bidang Bahasa Timur dan Bahasa-Bahasa Barat, Fakultas Adab, Universitas Iskandariyah pada tahun 1963 M; 2) Diplomasi umum di pendidikan, Fakultas Tarbiyah, Universitas Ainu Syamsi pada tahun1963 M. Riwayat pekerjaan Mahmud Kamil An-Naqoh: 1) Rektor (pengawas) dibidang media seperti radio, televisi sejak tahun 1963 M sampai tahun $1968 \mathrm{M}$; 2) Asisten di bagian kurikulum dan metodologi pendidikan di Tarbiyah, Universitas Ainu Ayamsi sejak tahun 1968 M sampai tahun 1972 M; 3) Dosen bantu di bidang kurikulum dan metode pendidikan di Fakultas Pendidikan, Universitas Ainu Syamsi sejak tahun 1972 M sampai tahun 1975 M; 4)Dosen di bidang di bidang kurikulum dan metode pendidikan sejak tahun 1975 M sampai tahun $1980 \mathrm{M}$; 5) Prof pembantu di bidang di bidang kurikulum dan metode pendidikan sejak tahun 1980 M sampai tahun 1985 M; 6) Wakil Fakultas Tarbiyah di Universitas Ainu Syamsi Studi Magister. ${ }^{17}$

Karya-karya Mahmud Kamil An-Naqoh yang terkenal: 1) Asāsiyatul Manhaj wa Tanżimātuhu tahun 1979 M; 2) Al 'Arabiyyah Lughati Juz 1 tahun 2001 M; 3) Al 'Arabiyyah Lughati Juz 2 tahun 2003 M; 4) Mihnatu An Nāsyat Al Madrasi wa Nahnu Nunādi bi Bināil Insān tahun 1979 M; 5) Mu'allimu Al Mauhūbin wa Dauruhu Al-Mujaddid tahum 2003 M; 6) Ta’limu Al-Lughah Al ‘Arabiyah li An Nāṭiqīn bi Lughātin Ukhra: Asasuhu, Madākhiluhu wa țuruqu Tadrīsihi tahun 1985

${ }^{15}$ Akmal Firdaus Sultra, "Fikrotu Mahmud Kāmil An Nāqoh fi Ta’līm Mahārōt Al Lughat Al 'Arobiyyat Lighairi An Nāțiqīna”, 64.

${ }^{16}$ Akmal Firdaus Sultra, "Fikrotu Mahmud Kāmil An Nāqoh fi Ta’līm Mahārōt Al Lughat Al ‘Arobiyyat Lighairi An Nāțiqīna”, h. 64.

${ }^{17}$ Ibid, h. 64-66 
M; 7) Barāmiju Ta 'ìmu Al `Arabiyah li Al-Muslimīna An Nāṭiqīna bi Lughātin Ukhra fĩ ḍoui Dawāfihim tahun 1985 M; 8) Thorōiq Tadrisi Al Lugha Al 'Arabiyah li Ghairi An Nāțiqīna bihā tahun 2003 M; 9) Al Kitāb Al Asāsi li Ta'limi Al Lugha li An Nāțiqīnā bi Lughatin Ukhra tahun 1983 M; 10) Ta'lìmu Al Lugha Ittisholiyan baina Al Manhāji wa Al Istirōtijiyāt tahun 2006 M.18

Adapun kedudukan Mahmud Kamil An-Naqoh di beberapa organisasi: 1) Ketua forum organisasi Mesir terhadap kurikulum dan metode pendidikan; 2) Anggota organisasi Mesir terhadap pendidikan komperatif dan kantor kependidikan; 3) Anggota majelis Amerika terhadap pembelajaran bahasa Asing; 4) Anggota organisasi Lisanu Al-'Arab untuk menjaga bahasa Arab di Kairo; 5) Anggota akademik penelitian ilmiyah dan teknologi (kelompok pendidik dan ilmu pisikologi); 6) Anggota komisi pendidikan di dewan kebudayaan. ${ }^{19}$

\section{Epistimologi Kurikulum Bahasa Arab Perspektif Mahmud Kamil An-Naqoh}

\section{Landasan Penyusunan Kurikulum Bahasa Arab}

Mengingat pentingnya fungsi dan peran kurikulum dalam dunia pendidikan, maka penyusunan kurikulum tidak dapat dilakukan secara sembarangan, melainkan berdasarkan landasan-landasan yang kuat, yang didasarkan pada hasil-hasil pemikiran dan penelitian yang mendalam. Penyusunan kurikulum yang tidak didasarkan pada landasan yang kuat, akan dapat berakibat fatal terhadap kegagalan pendidikan itu sendiri.

Mahmud Kamil An-Naqoh membagi landasan penyusunan kurikulum bahasa Arab ke dalam empat aspek, yaitu: (1) dasar linguistik/al-lughawiyyah, (2) dasar sosial-budaya/aśqōfiyyah, (3) dasar psikologi/an-nafsiyyah, dan (4) dasar pendidikan/at-tarbawiyyah. Kemudian dari keempat aspek tersebut, beliau masih membagi lagi menjadi lima aspek, yaitu: (1) pengalaman dan praktik bahasa/alkhibroh al-lughawiyah wa al-mumārosah, (2) sifat bahasa Arab/țobīatu al-lughah al-'Arabiyah, (3) sosial budaya Arab/aś-sंaqōfah al-'Arabiyah, (4) sifat pembelajar bahasa (peserta didik)/țobīatu al-muta allimin lilughah, dan (5) sifat pengajaran bahasa Arab sebagai bahasa Asing/țobīatu ‘amaliyatu ta`lim al-'Arabiyah bi ìtibārohā lughah ajnabiyah. ${ }^{20}$

${ }^{18}$ Ibid, h. 67-68

${ }^{19}$ Ibid, h. 66

${ }^{20}$ Mahmud Kamil An-Naqoh,Ta 'lìmu Al Lugha Ittisholiyan baina Al Manhāji wa Al Istirōtijiyāt (Rabat: ISESCO, 2006), 92. 
Pengalaman dan Praktik Bahasa (al-khibroh al-lughawiyah wa almumārosah)

Sebagaimana menurut Mahmud Kamil An-Naqoh, bahwa kurikulum adalah seperangkat sikap dan pengalaman bahasa yang dipersiapkan, dipilih, direncanakan, dan diatur agar dapat dialami, dipelajari, serta dipraktikkan oleh pembelajar bahasa dengan cara mendengarkan, berbicara, membaca dan menulis. ${ }^{21}$ Definisi tersebut sejalan dengan definisi yang dingkapkan oleh Zubaidi, bahwa kurikulum adalah segala apa yang dirancang, berisi jumlah mata pelajaran yang harus dipelajari oleh peserta didik, kegiatan-kegiatan yang harus diikuti, dan juga pengalaman belajar yang diharapkan dapat dicapai oleh peserta didik. ${ }^{22}$ Oleh karena itu, Mahmud Kamil An-Naqoh memasukan pengalaman bahasa sebagai salah satu dari dasar yang dijadikan landasan penyusunan kurikulum bahasa Arab.

Adapun yang dimaksud dengan pengalaman bahasa adalah sebuah sikap berbahasa yang disiapkan agar peserta didik dapat membiasakan dan mempraktikkannya untuk penggunaan bahasa itu sendiri. Dengan kata lain, berdasarkan pengalaman tersebut, peserta didik dapat mengetahui sekumpulan informasi atau pengetahuan tentang bahasa dan tata cara penggunaan bahasa tersebut, atau dapat mengetahui keterampilan-keterampilan berbahasa itu sendiri, seperti keterampilan mendengar, berbicara, membaca dan menulis.

Dalam kegiatan pembelajaran, peserta didik dibimbing, dibantu dan diarahkan agar memiliki pengetahuan dan pemahaman berupa pengalaman belajar, atau suatu cara bagaimana mempersiapkan pengalaman belajar bagi peserta didik. ${ }^{23}$ Intinya, pengalaman berbahasa bertujuan agar peserta didik dapat menggunakan dan mempraktikan bahasa dalam kehidupan mereka yang sesuai dengan tujuan dan motivasi dari penggunaan bahasa tersebut.

Kurikulum sebagai program pembelajaran yang terencana secara sistematis yang memberikan berbagai pengalaman belajar bahasa Arab kepada peserta didik yang mencukup aspek pengetahuan, sikap dan keterampilan, baik dalam lingkungan sekolah ataupun di luar sekolah, dengan tujuan agar peserta

${ }^{21}$ Ibid.

${ }^{22}$ A. Zubaidi, "Model-Model Pengembangan Kurikulum”, Jurnal Cendekia, Vol. 13, No. 1 $2015,108$.

${ }^{23}$ Rusmono, Strategi Pembelajaran dengan Problem Based Learning (Bogor: Ghalia Indonesia, 2012), 6. 
didik mampu berkomunikasi dengan bahasa Arab serta memahami kebudayaan Arab. $^{24}$

Menurut Mahmud Kamil An-Naqoh, ada dua jenis pengalaman bahasa yang dapat dilakukan oleh peserta didik dalam menguasai pengetahuan dan keterampilan berbahasa, yaitu: pertama, pengalaman secara langsung, yang artinya peserta didik mempelajari bahasa dari penutur asli bahasa tersebut. Kedua, pengalaman secara tidak langsung, artinya mempelajari bahasa bukan dari penutur asli, melainkan melalui buku atau materi yang telah diorganisir oleh Negara tempat tinggal pembelajar bahasa tersebut, atau melalui rekaman suarasuara penutur asli, tanpa bertemu langsung dengan mereka. ${ }^{25}$

Adapun mengenai syarat-syarat yang harus diperhatikan berhubungan dengan pengalaman bahasa, agar tujuan yang telah dirumuskan dapat tercapai, Mahmud Kamil An-Naqoh membaginya sebagaui berikut: (1) keberlanjutan/alistimrōr, artinya dalam sikap bahasa yang telah disiapkan harus berlanjut, mulai dari tahap yang mudah, sedang, hingga sulit. Tidak berhenti pada satu tahap saja, (2) integrasi/at-takāmul, artinya pembelajaran bahasa Arab harus terintegrasi dan saling terkait antara satu keterampilan dengan keterampilan yang lain, (3) bertingkat/at-tātabu', artinya pembelajaran bahasa dimulai dengan mengajarkan aspek-aspek yang mudah dan sederhana terlebih dahulu, kemudian ke aspek yang sulit, bukan sebaliknya atau tergantung kemauan pendidik saja, dan (4) ketenangan/al-atjān, artinya dalam penyusunan kurikulum jangan sampai mengandung aspek yang tidak berhubungan dengan pembelajaran bahasa, baik pengetahuan bahasa maupun keterampilan berbahasa.

\section{Sifat dan Karakteristik Bahasa Arab (țobī'atu al-lughah al-'Arabiyah)}

Karena kurikulum yang disusun adalah kurikulum pembelajaran bahasa, maka perlu adanya memasukkan sifat dan karakteristik bahasa sebagai dasar landasan penyusunan kurikulum.

Karakteristik bahasa secara umum, yaitu (1) bahasa itu humanistik/manusiawi, artinya bahasa merupakan sesuatu yang berhubungan dengan manusia, sehingga yang mempelajari bahasa adalah manusia, bukan yang

${ }^{24}$ Walfajri, "Landasan Pengembangan Kuirkulum Bahasa Arab", 83.

${ }^{25}$ Mahmud Kamil An-Naqoh,Ta līmu Al Lugha Ittisholiyan baina Al Manhāji wa Al Istirōtijiyāt, 92. 
lainnya, (2) bahasa itu bunyi, hal ini berhubungan dengan fonologi bahasa, (3) bahasa itu pasti memiliki makna di dalamnya, yang terdiri dari simbol-simbol yang diketahui oleh pembicara dan pendengar, penulis dan pembaca. Sehingga tanpa pengetahuan menganai makna, maka komunikasi akan menjadi sulit, (4) bahasa itu memiliki sistem khusus dan teratur, yang menurut Abdul Chaer (2012), bahasa terdiri dari unsur-unsur atau komponen-komponen yang secara teratur tersusun menurut pola tertentu dan membentuk suatu kesatuan. ${ }^{26}$ dan (5) bahasa itu dinamis, artinya bahasa selalu berkembang dan berubah seiring dengan perkembangan zaman dan kehidupan manusia dari generasi ke generasi, seperti perubahan dalam tatanan fonologi, morfologi, kosa kata dan yang lainnya. Dari satu daerah ke daerah yang lain mengembangkan bahasa mereka secara efektif untuk memenuhi kebutuhan masyarakat daerah tersebut.

Adapun karakteristik bahasa Arab, yang harus diperhatikan ketika hendak membuat kurikulum adalah menurut Mahmud Kamil An-Naqoh, (1) bahasa Arab merupakan bahasa yang derivasi/isytiqāq, sehingga bahasa Arab menjadi bahasa yang fleksibel dan beraneka ragam. Hal ini juga diungkapkan oleh Rohman bahwa bahasa Arab memiliki metode isytiqāq dalam penurunan kosa katanya, sehingga mampu menyusun kata-kata baru. ${ }^{27}$ Kekayaan kosa kata bahasa Arab dibentuk melalui akar kata, lalu akar kata itu diungkapkan dengan berbagai macam bentuk lain yang memiliki arti yang berbeda-beda, (2) bahasa i'rab, (3) bahasa kaya bunyi, (4) bahasa tașrīf, (5) bahasa yang memiliki konsep waktu,dan sebagainya. ${ }^{28}$

Mengetahui karakteristik bahasa, terutama bahasa Arab menjadi satu keharusan dalam pembuatan kurikulum, karena hal tersebut merupakan salah satu cara untuk memasuki gerbang pemahaman mengenai bahasa tersebut. Apa lagi bahasa Arab memiliki ciri dan kekhususan yang berbeda dan mungkin tidak dimiliki oleh bahasa lain di dunia itu.

\section{Sosial Budaya Arab (aś-śaqōfah al-'Arabiyah)}

Mempelajari bahasa tak dapat dilepaskan dari mempelajari bagaimana bahasa tersebut digunakan dalam kehidupan sehari-hari, terutama bagaimana

${ }^{26}$ Abdul Chaer, Lingkuistik Umum (Jakarta: Rineke Cipta, 2012), 34.

${ }^{27}$ F. Rohman, "Strategi Pengelolaan Komponen Pembelajaran Bahasa Arab”, Arabiyāt: Jurnal Pendidikan Bahasa Arab dan Kebahasaaraban, Vol.1, No. 1, 2014, 66.

${ }^{28}$ Mahmud Kamil An-Naqoh,Ta'ìmu Al Lugha Ittisholiyan baina Al Manhāji wa Al Istirōtijiyāt, 96. 
bahasa tersebut dipengaruhi dan juga ikut membentuk budaya para penutur aslinya. Hal ini menyiratkan bahwa seorang yang mempelajari bahasa tertentu tanpa memahami budayanya berpotensi menjadi orang fasih yang bodoh.

Seperti yang kita ketahui bahwa berhasil atau tidaknya komunikasi antara seorang penutur Asing dengan penutur asli bahasa tidak hanya bergantung kepada tingkat kompetensi dalam komponen dan keterampilan lingkuistik yang diperoleh dari pengajaran bahasa saja. Para pembelajar juga perlu mempunyai pemahaman mengenai budaya bahasa target, seperti bagaimana mereka hidup?Bagaimana adat istiadat, sifat dan kebiasaan kehidupan mereka? Dan lain sebagainya, agar ia dapat memasuki tahap melakukan komunikasi dengan sikap yang positif mengenai lawan bicara yang budayanya berlainan. Tentu saja hal itu dapat dicapai apabila komponen budaya juga di masukkan ke dalam pengajaran bahasa sasaran.

Oleh karena itu, budaya Arab menempati posisi yang penting dalam pengajaran bahasa Arab kepada penutur non-Arab. Sehingga, dalam isi materi pembelajaran bahasa Arab, harus mencantumkan aspek budaya Arab. Dalam mengajarkan bahasa Arab, harus mengetahui aspek budaya merupakan salah satu cara untuk menemukan makna yang benar dan sesuai dari bahasa tersebut. Karena ketika bahasa tersebut dipraktikan untuk berkomuniaksi dengan orang Arab, kita harus memahami dengan benar budaya mereka.

Adapun menurut Mahmud Kamil An-Naqoh, dalam penyusunan kurikulum harus menyiapkan komponen-komponen mengenai budaya Arab yang harus dipelajari oleh peserta didik, sehingga budaya Arab tersajikan dengan benar dan tetap menghormati budaya pembelajar bahasa. ${ }^{29}$ Penyajian budaya juga harus sesuai dengan tujuan dan motivasi peserta didik dalam pembelajaran bahasa Arab, misalnya (1) konsep budaya Arab, (2) karakteristik budaya Arab, (3) sumber dan asal-usul budaya Arab, (4) dimensi budaya Arab pada masa lampau, sekarang dan masa akan datang, dan (5) tingkat fisik dan sikap budaya Arab.

Dari uraian di atas, dapat dipahami betapa hubungan antara bahasa dan budaya sangatlah erat dan tak dapat dipisahkan. Di mana bahasa (termasuk bahasa arab) adalah sub sistem dari budaya dan karena pada bahasa terdapat fungsi kebudayaan. Pertimbangan yang cermat harus dilakukan pada saat menentukan

${ }^{29}$ Mahmud Kamil An-Naqoh, Ta'lìmu Al Lugha Ittisholiyan baina Al Manhāji wa Al Istirōtijiyāt, 100. 
aspek budaya apa yang akan diajarkan, dengan menggunakan materi apa, melalui input linguistik apa dan bagaimana penerapannya dalam kelas. Hasil dan tujuan yang ingin dicapai pun haruslah dinyatakan dengan jelas.

\section{Jiwa Pembelajar Bahasa/Peserta Didik (țobīatu al-muta`allimin}

\section{lilughah)}

Salah satu asas penting dalam penyusunan kurikulum adalah landasan psikologi.Landasan psikologi penyusunan kurikulum menuntut untuk memperhatikan dan mempertimbangkan aspek peserta didik dalam pelaksanaan kurikulum. Sehingga pada saat pelaksanaan kurikulum apa yang menjadi tujuan kurikulum akan tercapai secara optimal.

Psikologi adalah ilmu yang mempelajari tentang perilaku manusia, sedangkan kurikulum adalah upaya menentukan atau mengorganisir program pendidikan untuk mengubah perilaku manusia. Oleh karena itu, penyusunan kutikulum harus dilandasi oleh psikologi sebagai acuan dalam menentukan apa dan bagaimana perilaku itu harus dikembangkan. Pengetahuan mengenai psikologi akan membantu para penyusun kurikulum untuk lebih realistis dalam memilih tujuan pendidikan. Dengan menerapkan landasan psikologi dalam proses penyusunan kurikulum, diharapkan pendidikan yang dilaksanakan relevan dengan hakikat peserta didik, baik penyesuaian dari segi materi atau bahan yang harus diberikan dan dipelajari maupun dari segi penyampaian dan proses belajar, serta penyesuaian dari unsur-unsur pendidikan lainnya.

Landasan ini berkaitan dengan potensi, kemampuan, kebutuhan, minat, bakat, kecenderungan, motivasi, perbedaan individual, perasaan, emosi, dan kejiwaan peserta didik.Penyusunan kurikulum pembelajaran bahasa Arab dapat dinilai efektif, berdaya guna, dan prospektif apabila dapat memenuhi kebutuhan psikologis dan memberi kepuasan batin peserta didik dalam belajar.

Adapun hal-hal yang akan dirumuskan berkaitan dengan memperhatikan psikologi peserta didik, yaitu: (1) menentukan tujuan umum pembelajaran atau tujuan umum kurikulum yang akan dibuat, (2) memilih pengalaman-pengalaman bahasa yang sesuai dengan level kemampuan peserta didik. Jangan sampai membuat kurikulum dengan mencantumkan pengalaman berbahasa yang untuk pembelajar level pemula, tetapi menggunakan pengalaman level lanjutan atau untuk yang sudah ahli dalam berbahasa, (2) memperhatikan strategi atau model 
pembelajaran yang sesuai dengan para peserta didik, (3) merencanakan kegiatankegiatan berbahasa yang sesuai dengan minat dan kebutuhan/tujuan peserta didik, (4) memperhartikan pemilihan media-media pembelajaran, seperti teknologi-teknologi yang sesuai dengan keadaan peserta didik, (5) memperhatikan instrumen evaluasi yang sesuai dengan peserta didik, dan (6) memperhatikan antara satu individu peserta didik dengan individu yang lain itu berbeda-beda, maka hal tersebut juga harus diperhatikan.

Sifat Pengajaran Bahasa Arab Sebagai Bahasa Asing (țobīatu 'amaliyatu ta 'lim al-'Arabiyah bi 'itibārohā lughah ajnabiyah)

Landasan ini terkait erat dengan sistem dan strategi pembelajaran.Penyusunan kurikulum harus mempertimbangkan penyusunan silabus, materi ajar, perencanaan dan strategi pembelajaran yang membuat tujuan pembelajaran itu dapat tercapai dengan efektif.Penetapan metode yang fleksibel, media yang efektif, penciptaan suasana dan lingkungan pembelajaran bahasa yang kondusif juga penting dipertimbangkan dalam pengembangan kurikulum pembelajaran bahasa. Pembelajaran harus beragam, dalam proses pembelajaran harus mengaitkan antara materi yang diajarkan dengan tujuan pembelajaran, pengalaman-pengalaman berbahasa dalam keterampilan-keterampilan harus bervariasi dan waktu pembelajaran harus tergorganisir dengan baik.

Penyusun kurikulum bahasa Arab juga harus mengetahui berbagai aspek seperti fonologi, morfologi, semantik, karakteristik bahasa Arab dan kemungkinankemungkinan kesulitan dalam mempelajari bahasa Arab, sehingga dapat memilih konten yang sesuai untuk pengajaran bahasa dan mengatasi kesulitan-kesulitan tersebut.

\section{Komponen-Komponen Kurikulum Bahasa Arab}

Adapun mengenai komponen-komponen yang ada dalam kurikulum bahasa Arab, Mahmud Kamil An-Naqoh membaginya menjadi lima bagian, yaitu: (1) tujuan/al-ahdāfu, (2) isi/materi/al-muhtawā, (3) metode/at-țruqu, (4) panduan pengajar/guru bahasa Arab/dalīlu mu'allim al-lughah al-'Arabiyah, dan (5) evaluasi/(at-taqwīm). ${ }^{30}$ Berdasarkan pembagian tersebut, dapat dilihat bahwa Mahmud Kamil An-Naqoh berbeda dalam merumuskan komponen kurikulum,

${ }^{30}$ Mahmud Kamil An-Naqoh,Ta līmu Al Lugha Ittisholiyan baina Al Manhāji wa Al Istirōtijiyāt, 92. 
yaitu dengan menambahkan komponen panduan untuk guru/pengajar bahasa Arab.

\section{Tujuan (al-ahdāf)}

Tujuan pendidikan untuk kurikulum pembelajaran bahasa Arab merupakan titik awal komponen kurikulum karena tujuanlah yang akan menentukan bagaimana materi/isi kurikulum, tingkatan/level bahasa dan budaya yang akan diajarkan, metode, sarana dan aktivitas pengajaran yang paling tepat. Tidak hanya itu, tujuan juga akan menjadi penentu pada tahap akhir, yaitu akan menentukan tingkat, metode dan model evaluasi, pengembangan dan modifikasi kurikulum selanjutnya.

Menurut Mahmud Kamil An-Naqoh, dalam menetukan tujuan kurikulum bahasa Arab untuk penutur Asing, harus memperhatikan: (1) tujuan tersebut harus jelas, (2) dapat diamati dan diukur secara akurat, (3) berdasarkan tingkatan peserta didik, dan (4) meliputi aspek koognitif, keterampilan dan sikap/perilaku. Adapun penyusunan tujuan harus terdiri dari: ${ }^{31}$

1. Tujuan umum dari kurikulum

2. Tujuan umum dari masing-masing keterampilan bahasa, yang kemudian diperinci dengan tujuan khusus.

3. Tujuan khusus untuk setiap level atau tingkatan pembelajaran, yaitu tingkat pemula, menengah dan lanjutan (ahli). Pada bagian ini kita harus menetapkan tujuan yang spesifik untuk masing-masing dari empat keterampilan bahasa dan oleh karena itu, setiap tingkat pembelajaran bahasa memiliki tujuan yang spesifik masing-masing dan saling berkelanjutan antara satu level dengan level yang lain.

\section{Isi/Materi (al-muhtawā)}

Materi kurikulum pada hakikatnya adalah isi kurikulum itu sendiri. Menurut Mahmud Kamil An-Naqoh, materi pembelajaran adalah sekumpulaninformasi yang memuat tentang linguistik, budaya dan komunikasi 
yang diberikan kepada peserta didik, dengan carapeserta didik terlibat di dalam mempelajarinya. ${ }^{32}$

Dalam memilih materi bahasa Arab yang benar, harus memperhatikan beberapa kriteria, sepertijiwapeserta didik, usia, level, tujuan, dan motivasi peserta didik.Selain itu, ada juga standar dalam hal pemilihan materi yang mendidik sehingga menjadi bahan yang cocok untuk sarana pembelajaran dan pengajaran bahasa. Ada beberapa hal yang harus diketahui dalam memilih materi, yaitu: (1) pendapat para ahli/pakar dalam pendidikan bahasa Arab untuk penutur Asing, pakar studi bahasa, pakar studi psikologi, serta pakar dalam budaya Arab, (2) motivasi, keinginan, tujuan, dan kegiatan bahasa peserta didik yang ingin mereka ikuti setelah mempelajari bahasa Arab, dan (3) tujuan kurikulum dan tingkat keterampilan bahasa yang diperlukan untuk kemampuan berbahasa.

Kriteria umum yang harus dipertimbangkan ketika memilih materi kurikulum pengajaran bahasa Arab kepada penutur asing, sebagai berikut: (1) relevansi materi dengan tujuan pembelajaran bahasa, yang berarti bahwa konten adalah terjemahan yang jujur dari tujuan dan memberikan pengalaman pendidikan untuk mencapai tujuan, (2) keaslian materi, berarti bahwa konten linguistik, budaya dan komunikatif secara ilmiah merupakan materi yang valid dalam hal informasi, pengetahuan, aturan, prinsip dan teori, dan yang terpenting,materidapat memberikan manfaat untuk peserta didik dan membantunya dalam mencapai tujuan mempelajari bahasa, dan (3) materi berkaitan dengan kebutuhan peserta didik, artinya materi merespons secara linguistik, budaya, dan komunikatif terhadap kebutuhan peserta didik dalam pembelajaran bahasa Arab.

Adapun dalam komponen isi/materi, Mahmud Kamil An-Naqoh, membaginya ke dalam beberapa tingkatan/level materi, seperti: (1) dari keseluruhan ke sebagian, (2) dari yang mudah ke yang sulit, (3) dari yang baru ke yang lama, dan (4) dari pengantar kepada pokoknya. ${ }^{33}$ Pembagian ini dikarenakan agar materi dapat diajarkan kepada peserta didik secara berurutan sehingga peserta didik juga dapat memahami pembelajaran secara teratur. Selain itu, agar materi dapat diajarkan secara kontinu/berkelanjutan, berarti bahwa konten dimulai pada tingkat pertama pembelajaran bahasa dengan pengalaman peserta

${ }^{32}$ Ibid, 125.

33Ibid, 127. 
didik yang masih sempit dan dangkal, dan saat konten berada pada tingkat yang lebih tinggi, maka akan ada perluasan dan pendalaman pengalaman bahasa peserta didik.

Pembagian tersebut sejalan dengan beberapa kriteria yang digunakan untuk menyusun materi kurikulum yang diungkapkan oleh Syaifuddin, yaitu: (1) continuitas/kesinambungan, (2) sequences/urutan, (3) integration/keterpaduan, dan (4) flexibility/keluesan-kelenturan. ${ }^{34}$

\section{Metode (at-torīqotu)}

Metode pembelajaran merupakan salah satu komponen penting di dalam kurikulum pembelajaran. Menurut Nana Sudjana yang dikutip oleh Darwyn Syah (2007), metode mengajar adalah cara yang digunakan oleh pendidik dalam mengadakan hubungan dengan peserta didik pada saat berlangsungnya pembelajaran. Atau dalam pengertian lain, metode mengajar merupakan cara-cara yang digunakan pendidik untuk menyampaikan bahan pembelaajran kepada peserta didik untuk mencapai tujuan. ${ }^{35}$

Oleh karena itu, pentingnya mengidentifikasi metode dan strategi pembelajaran yang paling tepat untuk setiap materi pembelajaran. Mahmud Kamil An-Naqoh, menyusun lima pedoman yang harus diperhatikan dalam pemilihan metode dan strategi pembelajaran, yaitu: (1) tujuan, (2) isi/konten, (3) persepsi guru tentang pengalaman peserta didik, tingkatan, motivasi, dan perbedaan individu peserta didik, (4) persepsi guru mengenai sifat bahasa Arab, karakteristik dan kesulitan dalam mempelajarinya, dan (5) persepsi dan pengetahuan guru tentang berbagai sumber pengajaran dan kegiatan bahasa Arab. ${ }^{36}$

Mengingat adanya hubungan yang erat antara metode pembelajaran dengan media dan aktivitas pembelajaran, maka dalam kurikulum pembelajaran bahasa Arab bagi penutur Asing juga harus memperhatikan materi dan metode pembelajaran dengan media pembelajaran yang paling tepat, seperti teknologi yang dapat membantu peserta didik untuk mempelajari bahasa Arab secara lebih

${ }^{34}$ M. Syaifuddin, "Strategi Pengembangan Komponen Kurikulum Bahasa Arab", Alfazuna: Jurnal Pembelajaran Bahasa Arab dan Kebahasaaraban, Vol. 2, No. 1, 2017, 83.

${ }^{35}$ Darwyn Syah, Perencanaan Sistem Pengajaran Pendidikan Agama Islam (Jakarta: Gaung Persada Press, 2007), 133.

${ }^{36}$ Mahmud Kamil An-Naqoh,Ta lìmu Al Lugha Ittisholiyan baina Al Manhāji wa Al Istirōtijiyāt, 128. 
efektif dan memberikan pengalaman kepada peserta didik meskipun tidak secara langsung, misalnya jika bahasa Arab dipelajari di luar Negara-Negara Arab, maka perlu menampilkan percakapan antara orang Arab melalui sarana audio-visual atau teknologi lainnya, ${ }^{37}$

\section{Panduan Guru Bahasa Arab (dalīlu mu 'allim al-lughah al- Arabiyah)}

Panduan guru dalam pengajaran bahasa Asing dalam hal ini bahasa Arab, bagi Mahmud Kamil An-Naqoh, merupakan hal yang sangat penting, karena biasanya seseorang yang mengajar bahasa Arab di luar Negara Arab, bukan merupakan penutur asli bahasa Arab, sehingga panduan untuk guru yang mengajarkan bahasa Arab, dimasukkan ke dalam komponen kurikulum pembelajaran bahasa Arab untuk menghindari kesalahan-kesalahan di dalam pengajaran. $^{38}$ Adapun panduan tersebut berisi di antaranya: (1) dasar-dasar persiapan materi pembelajaran yang akan diajarkan oleh guru, (2) sumber persiapan materi dan model yang digunakan dalam mengajar, (3) tujuan pengajaran materi tersebut, (4) jenis latihan dan cara mengaplikasikannya, (5) metode, teknik, dan prosedur pengajaran yang paling tepat untuk digunakan dalam mengajarkan materi tersebut, (6) menyajikan contoh-contoh pengajaran, (7) usulan alat bantu/media pengajaran tambahan untuk memperkaya kegiatan pembelajaran, dan (8) usulan cara dan sarana untuk mengevaluasi hasil pembelajaran.

\section{Evaluasi (at-taqwīm)}

Sesungguhnya proses pendidikan itu tidak hanya sebatas sampai pada tahap pembelajaran. Akan tetapi, ketika proses pembelajaran selesai, khususnya seorang pendidik harus bertanya kepada diri pendidik sendiri mengenai bagimana pencapaian yang sudah diraih oleh peserta didik dalam belajar bahasa? Keterampilan bahasa apa yang sudah mereka kuasai? Atau apa kekurangan dari proses pembelajaran bahasa Arab yang telah dilaksanakan? Pertanyaanpertanyaan seperti inilah yang mengharuskan adanya evaluasi dalam proses pembelajaran bahasa, untuk mendiagnosis dan mengatasi kekurangan, khususnya yang berkaitan dengan peserta didik.

${ }^{37}$ Ibid.

38 Ibid, 129. 
Mahmud Kamil An-Naqoh, merumuskan beberapa hal yang harus diperhatikan dalam perancangan evaluasi, yaitu: (1) konsep evaluasi dan hubungannya dengan unsur-unsur kurikulum yang lainnya, dalam hal ini berkaitan dengan tujuan, isi, metode pengajaran, aktivitas pembelajaran, dan lain sebagainya, (2) konsep evaluasi dalam pengajaran bahasa Asing, dalam hal ini berkaitan dengan kemampuan berbahasa, baik menyampaikan dan menerima pesan, keterampilan berbicara, menulis, menyimak, dan membaca, (3) ketentuan/syarat proses evaluasi dari segi kebutuhan terhadap setiap komponen kurikulum, dan pemerolehan peserta didik terhadap kamampuan bahasa; mendengar, berbicara, membaca dan menulis, (4) langkah-langkah proses evaluasi, di antaranya adalah mengidentifikasi tujuan, kemudian menyiapkan alat ukur seperti tes, kartu penilaian, kartu observasi, dan lain sebagainya, dan (5) bentuk dan metode evaluasi, seperti esai, objektif, tahririyah, syafahiyah, dan lain sebagainya. ${ }^{39}$

Pada dasarnya, tujuan, materi, metode dan media, evaluasi dan panduan guru yang ditambahkan oleh Mahmud Kamil An-Naqoh merupakan komponen utama di dalam suatu kurikulum. Menurut Rahmi, komponen-komponen tersebut saling berkaitan antara satu dengan yang lain. Tujuan berkaitan erat dengan bahasa pelajaran, proses belajar mengajar dan penilaian.Bahkan antara komponen tidak hanya berkaitan dengan satu arah saja, tetapi dua arah yang menunjukkan hubungan timbal balik.Setiap aspek tujuan mempunyai tingkat kesulitan yang berbeda-beda.

\section{PEMBAHASAN}

Persoalan epistemologi merupakan persoalan yang penting. Sebab tanpa mengetahui epistemologi yang jelas, seseorang tidak akan mengetahui tiga persoalan mendasar, yaitu hakikat, sumber, dan validitas pengetahuan. ${ }^{40}$ Menurut hemat penulis di dalam membahas perihal epistimologi kurikulum bahasa Arab, sebelum mengetahui perihal bidang-bidang yang digunakan sebagai landasan dalam penyusunan kurikulum bahasa Arab,hal yang harus diketahui terlebih dahulu adalah apa hakikat bahasa agar dapat dirumuskan seperti apa tujuan

${ }^{39}$ Ibid, 131.

40Walfajri, "Landasan Pengembangan Kuirkulum Bahasa Arab", An-Nabighoh: Jurnal Pendidikan dan Pembelajaran Bahasa Arab, Vol. 20, No. 1 (2018), 80. 
pembelajarannya, materi seperti apa yang akan dipelajari, bagaimana bentuk/proses pembelajarannya, dan bagaimana alat yang digunakan untuk mengetahui hasil dari proses pembelajaran bahasa Arab.

Begitu banyak pendapat para ahli mengenai hakikat bahasa yang masingmasing berusaha mengungkap apa sesungguhnya yang dimaksud dengan bahasa itu. Hal ini sangat penting, apalagi ketika dikaitkan dengan bagaimana mengajarkannya, termasuk bagaimana mendesain dan merencanakan sebuah pembelajaran bahasa yang dituangkan dalam penyusunan dan pengembangan kurikulum pembelajaran bahasa. Adapun dalam perspektif Mahmud Kamil AnNaqoh, mengemukakan hakikat bahasa secara lebih spesifik bahasa Arab adalah berhubungan dengan bagaimana seharusnya bahasa itu diajarkan dengan baik. ${ }^{41}$ Mahmud Kamil An-Naqoh berpegang pada pemahaman bahwa bahasa itu adalah ujaran bukan tulisan. Bahasa terbentuk dari kebiasaan-kebiasaan. Sehingga, menurut Mahmud Kamil An-Naqoh yang harus diajarkan adalah bahasa bukan tentang bahasa, akan tetapi bahasa itu sendiri.

Berdasarkan hakikat bahasa menurut Mahmud Kamil An-Naqoh di atas, maka dapat dipahami bahwa keberhasilan seorang pembelajar bahasa dalam perspektif Mahamud Kamil An-Naqoh adalah ketika pembelajar bahasa tersebut telah mahir di dalam keterampilan berbicara (kalām). Menurut Mahmud Kamil AnNaqah, urgensi kemahiran berbicara dalam konteks pembelajaran bahasa Asing terdapat pada aspek lisan pada bahasa itu sendiri. ${ }^{42}$ Aspek berbicara merupakan aspek utama dalam kurikulum pembelajaran bahasa Asing. ${ }^{43}$

Pendapat tersebut jelas mengindikasikan bahwa kemahiran berbicara (kalām) mengisyaratkan keberhasilan seseorang dalam berbahasa dan mengetahui bahasa tersebut.Karena kemahiran ini sangat terkait dengan pelafalan, gramatika/kaidah bahasa, kosakata, keterampilan mendengarkan, dan lain-lain. Oleh karena itu, pembelajaran bahasa Arab hendaknya diorientasikan pada penguasaan kompetensi komunikatif, artinya pembelajaran bahasa Arab tidak

${ }^{41}$ Mahmud Kamil An-Naqoh dan Rusydi Ahmad Tuaimah, Thorōiqo Tadrisi Al Lugha Al 'Arabiyah li Ghairi An Nāțiqina bihā (Rabat: ISESCO, 2003), 89.

${ }^{42}$ Mahmud Kamil An-Naqoh, Ta'limmu Al Lughah Al 'Arabiyah li An Nāțiqīn bi Lughātin Ukhra: Asasuhu, Madākhiluhu wa țuruqu Tadrīsihi (Makkah: Jamiatul Ummul Quro, 1985), 151.

${ }^{43}$ Yazid Hadi, "Pembelajaran Mahārat Al Kalām Menurut Rusdy Ahmad Thu'aimah dan Mahmud Kāmil An Nāqoh", 67. 
sekedar bertujuan pada penguasaan tentang kaidah tata bahasa saja (nahwusharaf), namun juga mampu menggunakan bahasa Arab sebagai alat komunikasi.

Dengan adanya pemahaman epistemologi yang benar, seseorang akan mudah melacakjalan mana pengetahuan ditemukan dan alat apa yang mesti digunakan. Adapun berkaitan dengan epistimologi kurikulum pembelajaran bahasa Arab, maka hal selanjutnya yang harus diketahui setelah hakikat bahasa adalah mengenai sumber yang menjadi landasan-landasan dalam penyusunan kurikulum bahasa Arab.

Sebagaimana yang telah dijelaskan pada bagian hasil penelitian, dalam penyusunan kurikulum bahasa Arab, terdapat lima bagian yang dapat dijadikan sebagai landasan penyusunan kurikulum bahasa Arab perspektif Mahmud Kamil An-Naqoh, yaitu (1) pengalaman dan praktik bahasa/al-khibroh al-lughawiyah wa al-mumārosah, (2) sifat bahasa Arab/țobīatu al-lughah al-'Arabiyah, (3) sosial budaya Arab/aś-saqōfah al-'Arabiyah, (4) sifat pembelajar bahasa (peserta didik)/țobīatu al-muta'allimin lilughah, dan (5) sifat pengajaran bahasa Arab sebagai bahasa Asing/țobīatu ‘amaliyatu ta'lim al-`Arabiyah bi’itibārohā lughah ajnabiyah.

Kelima landasan yang telah diuraikan di atas, memiliki hubungan yang saling berkaitan. Pada landasan pertama, pengalaman linguistik tidak dapat ditentukan dan dipilih tanpa didasarkan pada budaya Arab, karena bahasa membawa budayanya, yaitu budaya penuturnya adalah landasan ketiga, dan pengalaman linguistik ini dengan konten budayanya juga dapat dipilih dan dipersiapkan dengan baik hanya berdasarkan sifat dan karakteristik pembelajarnya. Dari penutur non-Arab, maka pelajar mempengaruhi pengalaman linguistik dan budaya yang diberikan kepadanya, dan pengalaman ini juga mempengaruhi pelajar dalam hal sarana untuk belajar bahasa. Selain itu, pengalaman linguistik dan budaya yang ditawarkan dalam kurikulum diatur oleh sifat dan karakteristik bahasa Arab, yang merupakan landasan kedua. Artinya bahwa pengalaman linguistik ini berasal dari bahasa dan pengalaman ini harus konsisten dengan sifat bahasa dan karakteristiknya.

Berdasarkan uraian di atas, konstruksi epistimologi kurikulum pendidikan bahasa Arab menurut perspektif Mahmud Kamil An-Naqoh dapat digambarkan sebagai berikut: 


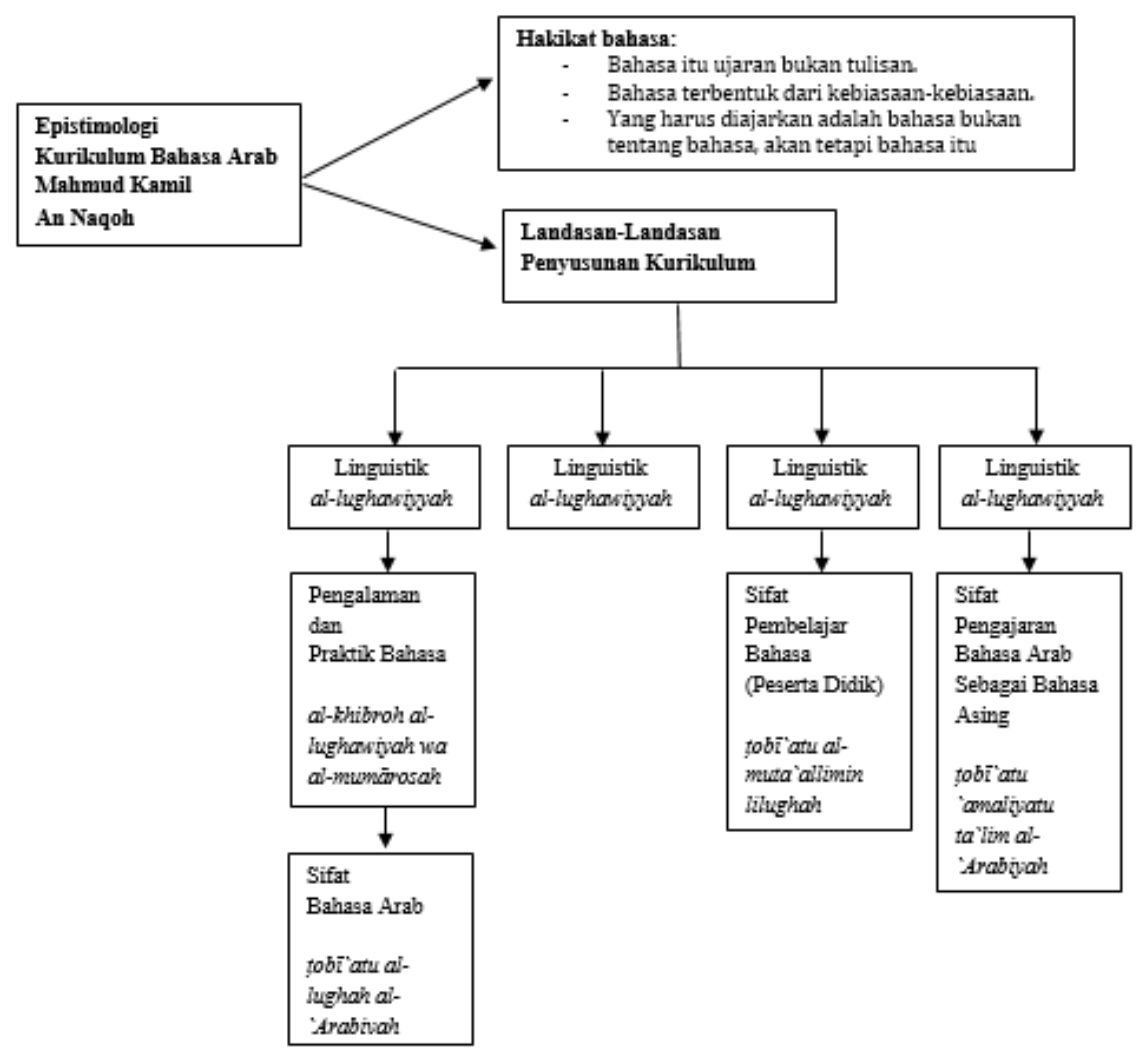

\section{Gambar 1. Konstruksi Epistimologi Kurikulum Bahasa Arab Perspektif Mahmud Kamil An Naqoh}

Dari epistimologi kurikulum bahasa Arab tersebut, maka dapat diketahui alasan dibalik perumusan isi komponen-komponen dalam kurikulum. Tidak hanya itu, validitas ilmu bahasa Arab yang diajarkan kepada peserta didik selama proses pembelajaran juga dapat ditelusuri dan dipahami dengan jelas. Misalnya, mengapa dalam pembelajaran bahasa Arab lebih menekankan pada aspek komunikatif, sehingga pemberian pengalaman belajar dan penyusunan komponen kurikulum lainnya ditujukan untuk menikangkatkan kemampuan peserta didik dalam keterampilan berbahasa Arab. Karena berangkat dari hakikat bahasa dan hal-hal yang dijadikan landasan dalam penyusunan kurikulum adalah untuk tujuan meningkatkan keterampilan peserta didik dalam menggunakan bahasa Arab, khususnya dalam berkomunikasi. 


\section{KESIMPULAN}

Dalam penyusunan kurikulum bahasa Arab, Mahmud Kamil An-Naqoh memahami hakikat bahasa sebagai: (1) ujaran bukan tulisan, (2) terbentuk dari kebiasaan, (3) dan yang harus diajarkan adalah bahasa itu sendiri, bukan tentang bahasa.Kemudian Mahmud Kamil An Naqoh meletakkan landasan pengalaman dan praktik bahasa sebagai landasan pertama, karena di dalam pembelajaran bahasa Asing, pembelajar harus dibawa pada pengalaman dan praktik dengan menggunakan bahasa sasaran tesebut. Tidak hanya sekedar diberi pengetahuan mengenai bahasa target, melainkan mereka terlibat langsung di dalam penggunaannya.Kemudian disusul dengan dasar karakteristik bahasa, sosial budaya, psikologi peserta didik sebagai pembelajar bahasa, dan tabi at pembelajaran bahasa Arab sebagai bahasa Asing. Keseluruhan landasan tersebut saling berkaitan satu sama lain, hingga melahirkan komponen-komponen kurikulum.

\section{DAFTAR PUSTAKA}

An-Naqoh, Mahmud Kamil. Ta'lìmu Al Lughah Al 'Arabiyah li An Nāțiqīn bi Lughātin Ukhra: Asasuhu, Madākhiluhu wa țuruqu Tadrīsihi. Makkah: Jamiatul Ummul Quro, 1985.

An-Naqoh, Mahmud Kamil, dan Rusydi, Ahmad Thuaimah. Ta'limu Al Lugha Ittisholiyan baina Al Manhāji wa Al Istirōtijiyāt. Rabat: ISESCO, 2006.

------. Thorōiqo Tadrisi Al Lugha Al 'Arabiyah li Ghairi An Nāțiqina bihā. Rabat: ISESCO,2003.

Burhanudin, Yusuf Enjang. "Implementasi Kurikulum Bahasa Arab di Perguruan Tinggi Agama Islam (PTAI) di Indonesia", Tarling:Jurnal of Language Education,Vol. 1, No. 01, 42-61,2017. Availbale at DOI 10.24090/TARLING.V1I1.1121

Chaer, Abdul. Linguistik Umum.Jakarta: Rineka Cipta, 2012.

Chotimah, Nur. "Urgensi Filsafat Bahasa dalam Pengembangan Kurikulum Pembelajaran Bahasa Arab", Turats: Jurnal Kajian Ilmu Pendidikan Bahasa dan Peradaban,Vol. 7,No. 1, 2015.

Hadi, Yazid. "Pembelajaran Mahārat Al Kalām Menurut Rusdy Ahmad Thu`aimah dan Mahmud Kāmil An Nāqoh", Al Mahāra: Jurnal Pendidikan Bahasa Arab, Vol. 5, No.01, 63-84,2019.

Available at DOI: https://doi.org/10.14421/almahara.2019.051-04 
Humaidi. "Epistimologi Kurikulum Pendidikan Sains”,Jurnal Pendidikan Sains,Vol. 2, No. 02, 263-284, 2013.

Available at DOI: https://doi.org/10.14421/jpi.2013.22.263-284

Muhzin, N. "Pengembangan Kurikulum Pendidikan Bahasa Arab (Kajian Epistimologi)", An-Nābighah: Jurnal Pendidikan dan Pembelajaran Bahasa Arab,Vol.19, No. 01, 85-106,2017.

Available at D0I: http://dx.doi.org/10.32332/an-nabighoh.v19i1.759

Nurcholis, Ahmad dan Basmah, Salaeh. "Epistimologi Kurikulum Bahasa Arab di Sekolah Menengah Mutawasitah Piraya Nawin Klonghin Wittaya Patani Thailand Selatan", Arabi: Journal of Arabic Studies, Vol. 4, No. 01, 76-86, 2019.

Available at DOI: http://dx.doi.org/10.24865/ajas.v4i1.124

Rohman, F. "Strategi Penngelolaan Komponen Pembelajaran Bahasa Arab", Arabiyāt: Jurnal Pendidikan Bahasa Arab dan Kebahasaaraban, Vol. 1, No. 1, 63-78, 2014.Available at D0I: $\underline{10.15408 / a . v 1 i 1.1131}$

Rusmono. Strategi Pembelajaran dengan Problem Based Learning.Bogor: Ghalia Indonesia, 2012.

Sukardi. Metodologi Penelitian Pendidikan: Kompetensi dan Prakteknya.Jakarta: Bumi Aksara.2010.

Sultra, Akmal Firdaus. Fikrotu Mahmud Kāmil An Nāqoh fi Ta'līm Mahārōt Al Lughat Al 'Arobiyyat Lighairi An Nātiqiña.Tesis UIN Maulana Malik Ibrahim.Malang, 2016.

Syaifuddin, M. "Strategi Pengembangan Komponen Kurikulum Bahasa Arab", Alfazuna: Jurnal Pembelajaran Bahasa Arab dan Kebahasaaraban, Vol. 2, No. 1 , 72-90, 2017.Available at DOI: https://doi.org/10.15642/alfazuna.v2i1

Wahab, Muhbib Abdul. "Standarisasi Kurikulum Pendidikan Bahasa Arab di Perguruan Tinggi Keagamaan Islam Negeri", Arabiyāt: Jurnal Pendidikan Islam dan Kebahasaaraban, Vol. 3, No. 01, 31-51, 2016.

Available at DOI : $10.15408 / a . v 3 i 1.3187$

Walfajri. "Landasan Pengembangan Kurikulum Bahasa Arab", An-Nābighoh: Jurnal Pendidikan dan Pembelajaran Bahasa Arab, Vol. 20, No. 1, 79-96, 2018. Available at DOI: http://dx.doi.org/10.32332/an-nabighoh.v20i01.1086

Zubaidi, A. Model-Model Pengembangan Kurikulum. Jurnal Cendekia, Vol. 13, No. 1, 108-121, 2015. 